\title{
Effect of vertical mixing on short-term mycosporine-like amino acid synthesis in the Antarctic diatom, Thalasiossira sp.
}

\author{
MARCELO PABLO HERNANDO ${ }^{1}$, JOSE IGNACIO CARRETO ${ }^{2}$, MARIO CARIGNAN ${ }^{2}$ \\ and GUSTAVO ADOLFO FERREYRA ${ }^{3}$ \\ ${ }^{1}$ Facultad de Medicina, Universidad de Morón, Cabildo 134 (1708) Buenos Aires, Argentina. \\ E-mail: mphernando09@hotmail.com \\ ${ }_{2}^{2}$ Instituto Nacional de Investigación y Desarrollo Pesquero, C.C.175, (7600) Mar del Plata, Argentina. \\ ${ }^{3}$ Institut de Sciences de la Mer de Rimouski, Université du Québec à Rimouski, Canada.
}

SUMMARY: One of the adaptations whereby phytoplankton can alleviate damage induced by ultraviolet radiation (280-400 $\mathrm{nm}$ ) is the synthesis of mycosporine-like amino acids (MAAs). The synthesis of MAAs was studied after exposure of the Antarctic diatom Thalassiosira sp. isolated from Potter Cove (South Shetland Is., Antarctica) to 2 treatments with a solar simulator: surface (Sfix) and vertical mixing (Mix) irradiance conditions. Light exposure was simulated in daily cycles with maximum irradiance at noon. Only 2 MAAs, Porphyra-334 (82-85\%) and Shinorine (15-18\%), were identified. The concentration of the two compounds increased during experimental light exposure (50-55\%) and declined in the dark (10$15 \%)$. During the light period the synthesis rate of MAAs per unit of chlorophyll $a$ was higher in the Sfix treatment $(u=0.17$ $\mathrm{h}^{-1}$ ) than in the Mix treatment $\left(\mu=0.05 \mathrm{~h}^{-1}\right)$. In spite of the higher MAA levels, low cell numbers were observed in the Sfix treatment, suggesting that the algae synthesized photoprotective compounds at the expense of growth. Our results document overlapping effects of both daily light cycles and vertical mixing affecting the synthesis of MAAs. This, and the high thermal dissipation of the ultraviolet B radiation energy $(280-320 \mathrm{~nm})$ absorbed by these substances, suggest a rapid photoadaptive response of Thalasiossira sp. upon exposure to elevated irradiance in a stratified water column, as well as the complementary role of vertical mixing in photo-protection.

Keywords: mycosporine-like amino acids, vertical mixing, Antarctic diatom, photoadaptive response, UV.

RESUMEN: EFECTOS DE LA MEZCLA VERTICAL SOBRE LA SíNTESIS A CORTO PLAZO DE MICOSPORINAS (MAAs) EN LA DIATOMEA ANTÁRTICA THALASIOSSIRA SP. - La síntesis de micosporinas (MAAs) es una de las adaptaciones por las cuales el fitoplancton puede reducir los daños inducidos por la radiación ultravioleta (UVR, 280-400 nm). La síntesis de MAAs fue estudiada después de la exposición de la diatomea antártica Thalasiossira sp., aislada en Caleta Potter (Islas Shetland, Antártica), a dos tratamientos: condiciones simuladas de irradiancia en superficie (Sfix) y mezcla vertical (Mix). La luz fue simulada utilizando un simulador solar con ciclos diarios con irradiancia máxima al mediodía. Sólo se identificaron dos MAAs, Porphyra-334 (82-85\%) y Shinorina (15-18\%). La concentración de ambos compuestos aumentó durante la exposición a la luz (50-55\%) y declinó en oscuridad (10-15\%). Durante el período de luz, la tasa de síntesis de MAAs (calculada para cada tiempo dividiendo cada valor por el valor correspondiente de clorofila $a$ ) fue mayor en el tratamiento Sfix $\left(\mu=0.17 \mathrm{~h}^{-1}\right)$ comparada con el tratamiento Mix $\left(\mu=0.05 \mathrm{~h}^{-1}\right)$. A pesar de la alta concentración de MAAs, se observó un bajo número de células en el tratamiento Sfix, sugiriendo que las algas sintetizan los compuestos fotoprotectores a expensas del crecimiento. Nuestros resultados documentan una superposición de los efectos de la luz y la mezcla vertical, afectando la composición de ambas familias de MAAs. Esto, junto con la alta energía de disipación de radiación ultravioleta B (UVBR, 280-315 nm) por estas substancias, reflejan una respuesta fotoadaptativa rápida de Thalasiossira sp. en su exposición a alta irradiancia en una columna de agua estratificada, así como también el rol complementario de la mezcla vertical como factor de fotoprotección.

Palabras clave: micosporinas, mezcla vertical, diatomea antártica, respuesta fotoadaptativa, UV. 


\section{INTRODUCTION}

UV-absorbing compounds, especially mycosporinelike amino acids (MAAs), strongly absorb ultraviolet radiation (UVR, 280-400 $\mathrm{nm}$ ) in phytoplankton and macroalgae (Carreto et al. 1990a, Karsten et al. 1999; Shick et al. 1996). More specifically, MAAs absorb UVR in the 310 and $360 \mathrm{~nm}$ range, within the spectral region of major photodamage. The photoprotective function of MAAs has mostly been inferred from their efficient UVR absorption and from the experimental evidence that biosynthesis and accumulation of MAAs can be induced by exposure to photosynthetically available radiation (PAR, 400-700 $\mathrm{nm}$ ) and UVR (Bandaranayake 1998, Carreto et al. 1990a, b, Kräbs et al. 2004). Moreover, algae with higher MAA concentrations seem to be better protected against photodestruction of photosynthetic pigments and display better growth and motility (Neale et al. 1998a, 1998b, Karsten et al. 1999, Klisch and Häder 2002, Banaszak 2003). The identification of repair and photoprotective mechanisms that may allow Antarctic phytoplankton to survive and reproduce under natural UVR, and particularly under increased ultraviolet $\mathrm{B}$ radiation (UVBR) flux scenarios (Lubin et al. 1989), is a key to understanding the dynamics of carbon fluxes in the South Antarctic. Cullen and Lesser (1991), Neale et al. (1998b) and Hernando and Ferreyra (2005) suggested that the impact of solar radiation on Antarctic phytoplankton in the upper metres of the water column in the euphotic zone is significantly modulated by vertical mixing. Both the degree of exposure to UVBR and the balance between damage and repair are a function of mixing depth and mixing speed (Neale et al. 1998b). As phytoplankton is moved vertically, cells experience both different irradiance and spectral exposures. Therefore, mixing in water column is a key factor to be considered in evaluating MAA induction patterns (Ivanov et al. 2000, MacDonald et al. 2003).

The water column attenuates solar radiation, and the amount of energy received at a given depth depends not only on the surface irradiance, but also on the attenuation coefficient $\left(\mathrm{K}_{d}\right)$. The light-absorbing components in the aquatic system are the water itself, dissolved organic carbon (DOC), and coloured dissolved organic matter (CDOM), photosynthetic pigments, and the concentration of inorganic particles such as sediment run-off (Kirk 1994). Attenuation of UVR is higher than that of PAR as DOC and CDOM do not absorb within the visible light range.

It is still not fully understood what exactly regulates MAA synthesis in phytoplankton. Several studies suggest that the total irradiance (Carreto et al. 1990a, Neale et al. 1998b, Taira et al. 2005) in agreement with spectral quality of PAR and UVR (Carreto et al. 1990b, Riegger and Robinson 1997, Portwich and García-Pichel 2000, Kräbs et al. 2002, 2004) and the availability of assimilable nitrogen (Frame 2004) shape the process of MAA production. Experiments carried out with several species of Antarctic phytoplankton to identify the wavelengths which trigger MAA formation (Davidson et al. 1994, Villafañe et al. 1995, Helbling et al. 1996, Riegger and Robinson 1997, Hernando et al. 2002) indicate a high variability in the spectral induction pattern. In some species, MAAs accumulate in response to UVBR (Helbling et al. 1996), whereas in others induction is dependent on PAR, blue light and ultraviolet A radiation (UVAR) $(315-400 \mathrm{~nm})$, with no additional effects of UVBR (Bandaranayake 1998). The production of MAAs in the dinoflagellate Alexandrium catenella, for instance, is PAR-dependent. However, the synthesis was inhibited when the algae were additionally exposed to high UVBR (Carreto et al. 2002), suggesting that the synthesis of this putative protection mechanism is susceptible to UVBR in the dinoflagellate. In other algal groups, such as chlorophytes and criptophytes, MAAs were not synthesized or were not photoinduced upon exposure to either high PAR or UVR (Helbling et al. 1996, Riegger and Robinson 1997). In addition, in some species of cyanobacteria MAAs are mostly induced by UVBR and unaffected by UVAR and PAR (Sinha et al. 2002). It therefore seems that different photoreceptors are involved in MAA induction. It has been suggested that these photoreceptors are responsible for the regulation and production of species-specific MAA induction patterns in response to the environmental light regime (Carreto et al. 1990a, Riegger and Robinson 1997, Portwich and García-Pichel 2000, Kräbs et al. 2004).

Climate warming results in a decrease in sea ice during summer in polar regions, including the coastal regions of King George Island (Serreze et al. 2007, Schloss et al. 2008), which will alter water column stratification and mixed layer depth (Finkel et al. 2010). To improve predictions of recent changes in water column stratification in the area of the West Antarctic Peninsula, plankton physiologists need to determine how to quantify the key physiological responses of major bloom-forming species.

In the present study we examined the short-term (hours) MAA synthesis of a typical Antarctic bloom forming diatom, Thalassiosira sp. The algae were cultured and exposed to simulated solar radiation under static surface exposure conditions (Sfix treatment), as well as under changing irradiance intensity, and to variable spectral conditions (PAR: UVAR: UVBR) to simulate the vertical mixing in the water column (Mix treatment).

\section{MATERIALS AND METHODS}

\section{Isolation and culture of Thalassiosira sp.}

Thalassiosira sp. was isolated from the natural community of Potter Cove, King George Island (Antarctica, $62^{\circ} 14^{\prime} \mathrm{S}, 58^{\circ} 38^{\prime} \mathrm{W}$ ) one month before the start of the experiments, following Hernando et al. (2002). Isolated cells were grown in Pyrex ${ }^{\mathrm{TM}}$ vessels (exposed 

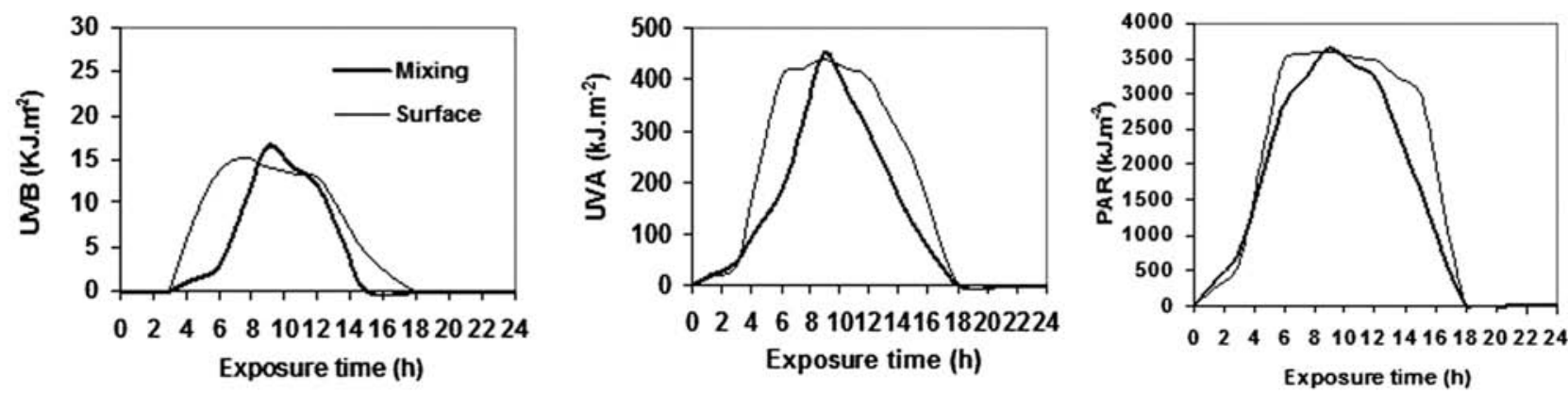

FIG. 1. - Daily irradiance time courses of PAR, UVAR and UVBR in the experimental exposures of Thalassiosira sp. cultures under simulated radiation and simulated surface static (Sfix treatment) and vertical moving (Mix treatment) incubations.

to PAR+UVA) with $\mathrm{f} / 2$ medium (Guillard and Ryther 1962). The culture vessels $(700 \mathrm{ml})$ were exposed to natural solar irradiance in the window of a refrigerated aquarium at $0-2^{\circ} \mathrm{C}$ for 10 days. Aliquots of exponentially growing Thalassiosira sp. were diluted with $0.7-\mu \mathrm{m}$ filtered seawater and addition of $\mathrm{f} / 2$ medium $(\mathrm{v} / \mathrm{v})$ before experimental incubations, reaching cell concentrations of $\sim 5-10 \times 10^{3}$ cell $\mathrm{ml}^{-1}$.

\section{Incubation experiments}

Two experiments, simulating surface exposure and mixing (Sfix and Mix treatments, respectively), were conducted in a solar simulator (SONSI) developed at the Alfred-Wegener Institute for Polar and Marine Research (AWI, Germany; see Bracher and Wiencke 2000 for a detailed description). The SONSI has a light source and 3 stacked filters of variable thickness (and therefore variable light transmission). The samples were illuminated with a 400-W metal halide lamp (Phillips MSR 400HR) containing a number of lanthanide rare earths, resulting in a solar-like continuum. The original lamp spectrum was modified by interferential chemical filters absorbing in different wavelength regions, in order to simulate the natural solar spectrum (Bracher and Wiencke 2000). Photons of wavelengths shorter than $280 \mathrm{~nm}$ were eliminated with a $6.5-\mathrm{mm}$-thick borosilicate glass (Schott, TEMPAX) filter.

In order to simulate local natural surface solar irradiance conditions, a series of measurements was performed in Potter Cove with a PUV-510 spectroradiometer (Biospherical Instruments Inc.). A surface solar UVBR scenario of 360 DU ozone, (UVBR: UVAR ratio $=0.05$ ) was simulated based on the UVBR:UVAR ratios calculated from the field measurements carried out on several days prior to the experiment. Solar inclination corresponding to the latitude and time of the year (November), as well as the daily sun inclination corresponding to a 24-h cycle, were simulated (Fig. 1). During the experiment, irradiance reaching the algae was monitored using a spectroradiometer specially designed for the SONSI at the AWI (Bracher and Wiencke 2000). The instrument records irradiances between 260 and $720 \mathrm{~nm}$ for each bandwidth. Vertical mixing conditions in the SONSI were adjusted
TABLE 1. - Daily doses of PAR, UVAR and UVBR during the experimental exposures of Thalassiosira sp. cultures

\begin{tabular}{lcc}
\hline & Static Surface & Vertical Mixing \\
\hline UVBR $\left(\mathrm{KJ} \mathrm{m}^{-2}\right)$ & 47.8 & 31.0 \\
UVAR $\left(\mathrm{KJ} \mathrm{m}^{-2}\right)$ & 1520 & 1086 \\
PAR $\left(\mathrm{KJ} \mathrm{m}^{-2}\right)$ & 14152 & 12045 \\
UVBR:UVAR & 0.031 & 0.028 \\
UVR:PAR & 0.11 & 0.09 \\
\hline
\end{tabular}

to simulate the mixing depth and speed determined during field experiments by Hernando and Ferreyra (2005) for the vertical movement of particles under the conditions of turbulent fluxes. We simulated a speed of mixing corresponding to an average of wind speed of $\sim 6 \mathrm{~m} \mathrm{~s}^{-1}$ in our Mix treatment, following the results from Schloss and Ferreyra (2002) for Potter Cove. Therefore, the depth of the simulated mixing layer was within the first few meters of the water column $(5-10 \mathrm{~m})$. Exposure of cells to UVR began at a simulated depth of $7 \mathrm{~m}$, increasing by 1 -m fixed steps each hour until the irradiance at the surface was reached. Cells were exposed for 2 hours to simulated surface conditions. Then, downward mixing was simulated at the same fixed steps to complete one mixing cycle. In the Sfix treatment, the algae were exposed to simulated surface conditions continuously to the solar irradiance corresponding to the latitude of Potter Cove at the time of the year. In this treatment the irradiance corresponding to a 24-h solar cycle was simulated. Maximum irradiance in the SONSI was reached after $9 \mathrm{~h}$ of exposure in both treatments (Fig. 1). UVBR below $5 \mathrm{~m}$ depth was not simulated during laboratory experiments due to the low irradiance values measured in the field and the lack of sensitivity of the SONSI spectroradiometer. The calculated daily doses of UVBR, UVAR and PAR are shown in Table 1. Quantity and quality of simulated surface irradiance were adjusted hourly to variable spectral attenuation coefficients, and the SONSI filter solutions were changed to simulate the underwater irradiance field. The recorded natural spectral coefficients were used for the preparation of the interference solutions. The initial Thalassiosira sp. cultures were placed in quartz tubes (100-ml volume), exposing cells to both UVR and PAR (280-700 nm). Incubation was main- 
tained at $3^{\circ} \mathrm{C}$. Three replicate samples were used for each treatment time point. After being filtered, the replicate samples had to be pooled to achieve enough volume for extraction of MAAs to reach the detection limit of the analysis method. Chl $a$, cell counts and MAA samples were taken every 3 hours.

\section{Determination of chlorophyll $a(\mathrm{Chl} a)$ and cell counts}

Chl $a$ was analyzed fluorometrically using a Shimadzu RF150 spectrofluorometer, following HolmHansen et al. (1965). A fourth quartz tube $(100 \mathrm{ml}$ volume) was exposed in the SONSI in order to determine Chl $a$. Unreplicated samples of $6 \mathrm{ml}$ from this last tube were filtered through a GF/F Whatman glass fibre filter and the photosynthetic pigments were extracted in absolute methanol at room temperature for 1 hour (Holm-Hansen and Riemann 1978). The spectrofluorometer was calibrated using a standard of Chl $a$ (Sigma). Three replicate samples for cell counting were kept in dark bottles and fixed with formalin previously neutralized with sodium borate (final concentration $0.4 \%$ ). Cells were enumerated with a microscope using a Sedgwick-Rafter counting slide according to Villafañe and Reid (1995).

\section{Growth measurements}

Instantaneous growth rates were determined according to the following equation:

$$
\mu=\ln \left(N_{1} / N_{n-1}\right) /\left(t_{1}\right)
$$

where $\mu$ is a specific growth rate constant $\left(\mathrm{h}^{-1}\right), t_{1}$ is the time in hours of measurement, $N_{1}$ is the parameter concentration at time $t_{1}$ and $N_{\mathrm{n}-1}$ is the parameter concentration at the previous time.

\section{MAA measurements}

For identification and quantification of MAAs, 8-ml samples were filtered onto Whatman GF/F filters and frozen $\left(-20^{\circ} \mathrm{C}\right)$. Filters were extracted with a Vibra Cell probe sonicator (Sonics and Materials; $1 \mathrm{~min}$, $100 \mathrm{~W}$ pulse mode, $0^{\circ} \mathrm{C}$ ) into $4-\mathrm{ml} 100 \%$ HPLC grade methanol. The extracts were filtered (Whatman GF/F) and dried using a centrifugal vacuum evaporator (Centrivap, Labconco, Co.). The residue was redissolved in $500 \mu \mathrm{l}$ of water and vortexed for $30 \mathrm{~s}$. After passing through a $100 \mathrm{k}$ Dalton ultrafilter (Ultraspin ${ }^{\mathrm{TM}}$ ), samples were analyzed by HPLC according to the method of Carreto et al. (2002). Briefly, the individual MAAs were separated by reverse phase gradient elution on an Alltima (Alltech) $\mathrm{C}_{18}, 5-\mu \mathrm{m}$ column (4.6 mm i.d. $\times 150$ $\mathrm{mm}$ length) protected by its own Alltech guard column (4.6 mm i.d. $\times 20 \mathrm{~mm}$ length) and thermostated to $30^{\circ} \mathrm{C}$. The gradient included an initial isocratic hold of $8 \mathrm{~min}$ with $100 \%$ Solvent A (0.2\% acetic acid) followed by a 12-min linear gradient from 0 to $40 \%$ of Solvent B (methanol:acetonitrile:0.2\% acetic acid, 25:25:50)

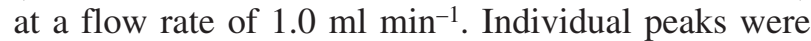
identified by their online absorption spectra, retention time and co-chromatography with authentic standards isolated from the red algae Porphyra sp. Quantification was made by peak-area integration at $330 \mathrm{~nm}$, using the following molar extinction coefficients: $\varepsilon_{334}=44700$ for Shinorine (Tsujino et al. 1980) and $\varepsilon_{334}=42300$ for Porphyra-334 (Takano et al. 1979).

\section{Statistical analyses}

In order to test for differences in Chl $a$, MAA/Chl $a$ concentration between treatments and differences in the ratio between Shinorine and Porphyra-334 during the exposure time, a one-way ANOVA analysis was applied. To analyze the significance of the differences observed between Porphyra-334 and Shinorine during exposure time, an ANCOVA analysis was applied. Repeated measures ANOVA (RMANOVA) were performed (Statistica, version 5.1) to determine the significance of the differences observed in the growth rate of Thalassiosira sp. for each treatment. In all cases assumptions for the test were verified.

\section{RESULTS}

\section{Chl $a$}

The initial cultures of Thalassiosira sp. used in the experimental treatments showed minor differences in the MAAs cell content and in the MAA/Chl $a$ ratio (Table 2). In order to normalize the Chl $a$ values, each exposure time point was divided by the initial concentrations of the culture used in the experiment. Despite the lower Chl a concentration of Thalassiosira sp. used for the Sfix treatment, the values were not significantly different $(F=3.02, P>0.05)$ from those used for the Mix one. Chl $a$ concentration in the Mix treatment increased during the light period and then stabilized at the beginning of the dark period. In contrast, the synthesis of Chl $a$ was arrested during the first few hours in the Sfix treatment and increased again after 6 hours of acclimation to Sfix irradiance conditions, until $12 \mathrm{~h}$ when the Chl $a$ concentration stabilized at similar levels to those observed in the Mix treatment (Fig. 2).

TABLE 2. - Values of MAA cell contents (pg cell ${ }^{-1}$ ), MAA/Chl $a$ (ng $\left.\mathrm{ng}^{-1}\right)$ ratio and Chl $a\left(\mu \mathrm{g} \mathrm{L}^{-1}\right)$ in Thalassiosira sp. cultures before the start of the experiments $(0 \mathrm{~h})$ and at the end of them $(24 \mathrm{~h})$.

\begin{tabular}{lcc}
\hline & $0 \mathrm{~h}$ & $24 \mathrm{~h}$ \\
\hline Static Surface & & \\
MAAs $\left(\mathrm{pg} \mathrm{cell}{ }^{-1}\right)$ & 35.3 & 49.17 \\
MAA/Chl $a(\mathrm{ng} / \mathrm{ng})$ & 1.17 & 1.46 \\
Chl $a\left(\mu \mathrm{g} \mathrm{L}{ }^{-1}\right)$ & 3.11 & 3.93 \\
Vertical Mixing & & \\
MAAs $\left(\mathrm{pg} \mathrm{cell}{ }^{-1}\right)$ & 40.8 & 37.89 \\
MAA/Chl $a(\mathrm{ng} / \mathrm{ng})$ & 1.44 & 1.41 \\
Chl $a\left(\mu \mathrm{g} \mathrm{L}{ }^{-1}\right)$ & 3.34 & 3.5 \\
\hline
\end{tabular}




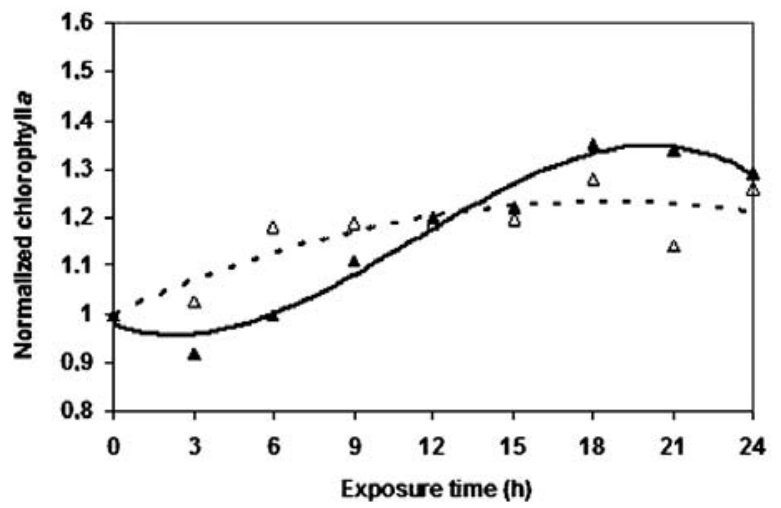

FIG. 2. - Time course of Chl $a$ (normalized to initial values) during exposures: Sfixed surface (filled triangles) and vertical mixing (open triangles).

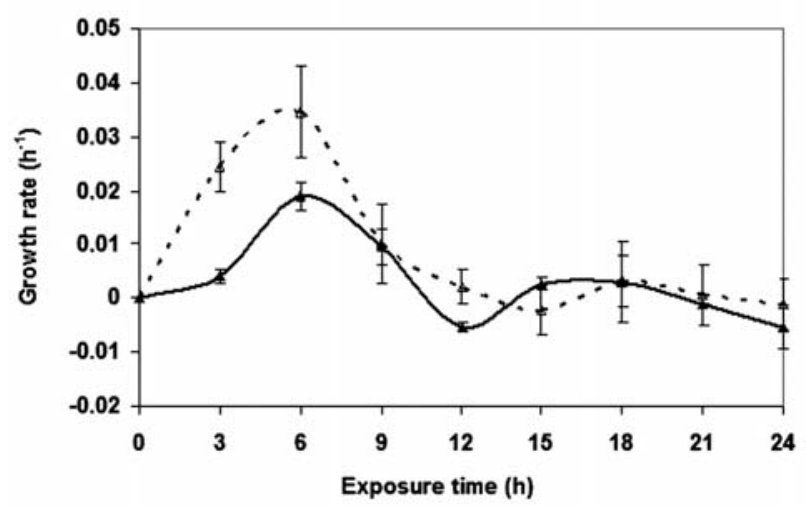

FIG. 3. - Cell instantaneous growth rate $\left(\mu=\mathrm{h}^{-1}\right)$ of Thalassiosira $s p$. as a function of the exposure time (hours) for surface and mixing treatments. Sfixed surface (filled triangles) and vertical mixing

(open triangles). Vertical bars are standard deviations.

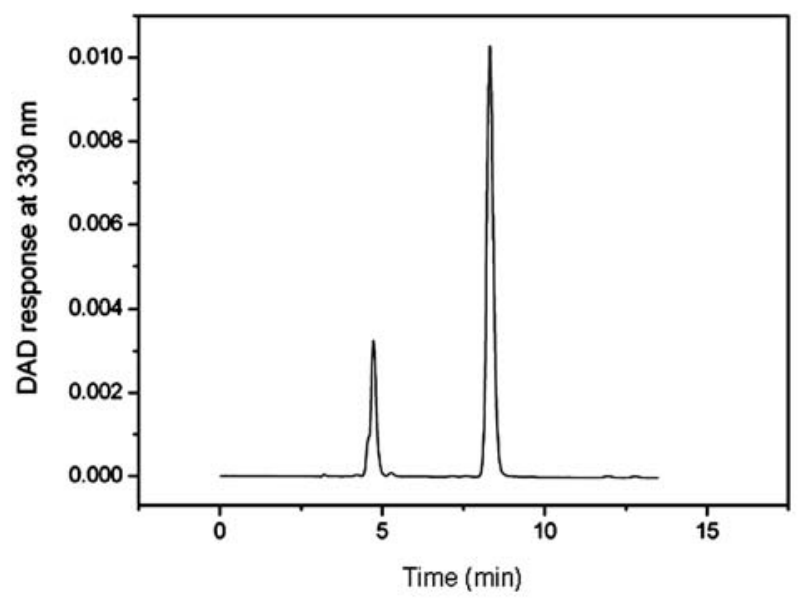

FIG. 4. - Typical chromatogram of cell extracts of the diatom Thalassiosira sp.: 1) Shinorine, 2) Porphyra-334. Detection at $330 \mathrm{~nm}$

\section{Cell growth}

Maximum growth rates were attained during the first $6 \mathrm{~h}$ of the experiment. RMANOVA analyses
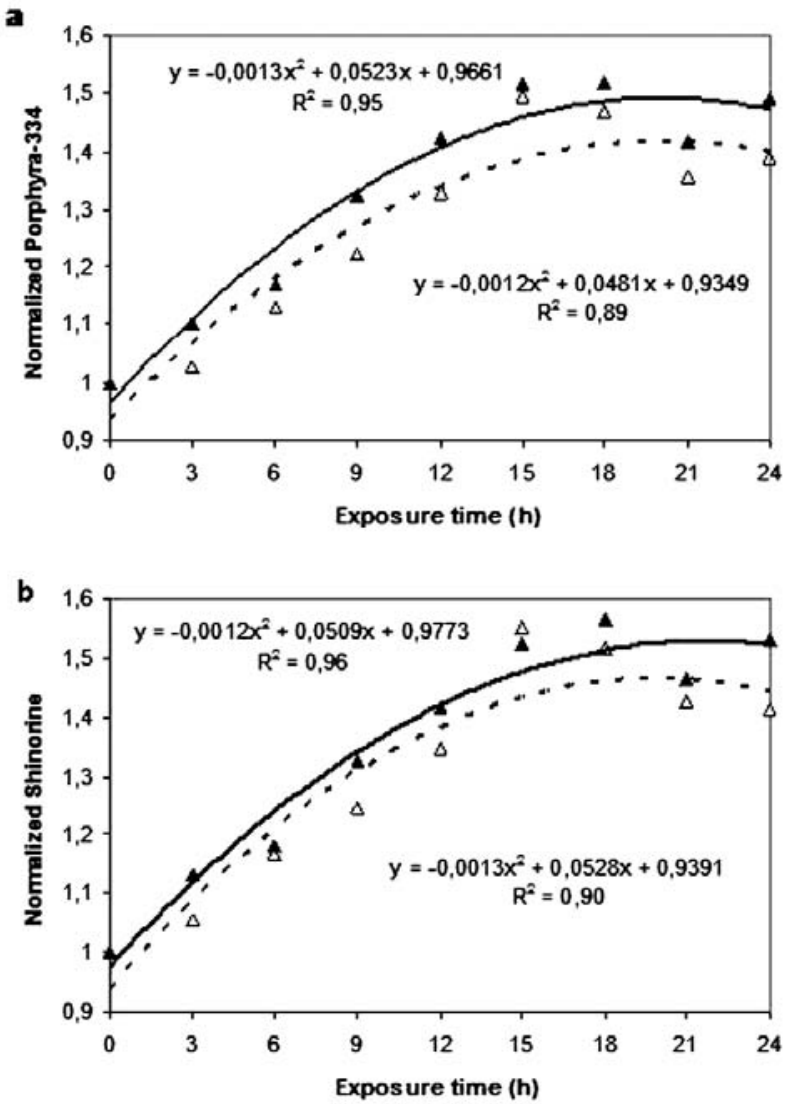

FIG. 5. - Time course of normalized to initial values cell contents of Porphyra-334 (a) and Shinorine (b) during exposures: Sfixed surface (filled triangles) and vertical mixing (open triangles).

for Thalassiosira sp. instantaneous growth rate $\left(\mathrm{h}^{-1}\right)$ showed a significant interaction between treatments and exposure time during the light period $(3-15 \mathrm{~h})$. Growth rates were significantly higher at hours 3, 6 and 12 in the Mix treatment than in the Sfix treatment (RMANOVA, $P<0.01$ ) (Fig. 3).

\section{MAAs identification and synthesis}

The chromatogram of the cell extract of the diatom Thalassiosira sp. showed a 2-peak MAA profile (Fig. 4): Porphyra-334 (relative proportion: $82-85 \%$ ) and Shinorine with lower concentrations (relative proportion: $15-18 \%$ ).

Rapid and significant increases in the concentrations of Porphyra-334 and Shinorine were observed from the beginning of the experiment in both treatments (Porphyra-334 $F=11.14$ and Shinorine $F=8.99$ for the Mix treatment $[P<0.05]$; Porphyra-334 $F=20$, and Shinorine $F=16.56$ for the Sfix treatment $[P<0.01])$ (Fig. 5). Under both conditions, MAA concentrations increased during the light period and decreased toward the beginning of the dark period. The concentration of both MAAs was significantly higher in the Sfix than in the Mix treatment (ANCOVA $F=9.79, P<0.01$ for Porphyra-334 and $F=9.87$, 


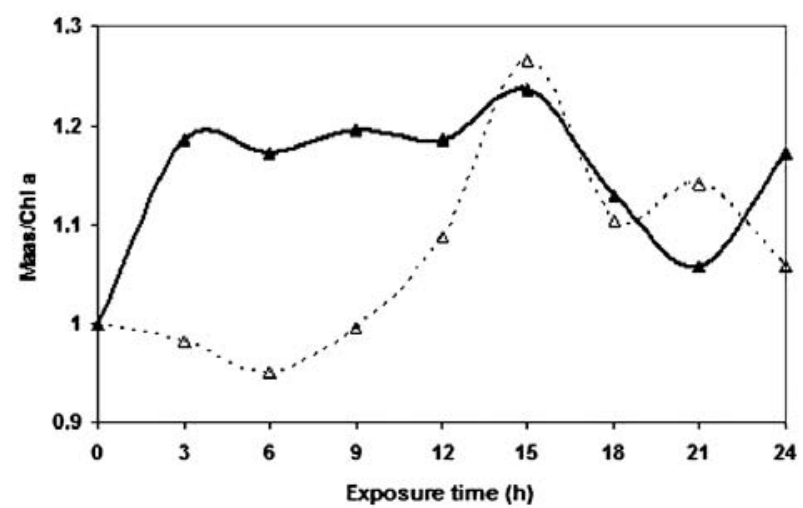

FIG. 6. - MAA/Chl $a$ ratios (normalized to initial values) during exposures: Sfixed surface (filled triangles) and vertical mixing (open triangles).

$P<0.01$ for Shinorine; Fig. 5 a and b respectively). A rapid increase in the $\mathrm{MAA} / \mathrm{Chl} a$ ratio was observed during the first 3 hours of the Sfix treatment. Despite the higher concentrations of MAAs observed in the Sfix treatment until $15 \mathrm{~h}$, the values of the ratio were not significantly different $(F=4.22, P>0.05)$ from those of the Mix treatment. After $15 \mathrm{~h}$ of exposure the MAA/Chl $a$ ratio remained almost constant $(F=0.01$, $P>0.05$ ) (Fig. 6).A marked increase in the Shinorine/ Porphyra-334 ratio was observed at the beginning of the experiment in both treatments, followed by a sharp decrease during the period of maximum light exposure, and a second increase following $15 \mathrm{~h}$ of exposure, which lasted until the end of the experiment. The Shinorine/Porphyra-334 ratio in the Mix treatment was significantly higher than that in the Sfix treatment during the first $15 \mathrm{~h}$ in the light period $(F=11.05, P<0.01)$ (Fig. 7). However the differences between exposure times for the light period (until 15 h) were not significant $(F=2.74, P>0.05)$.

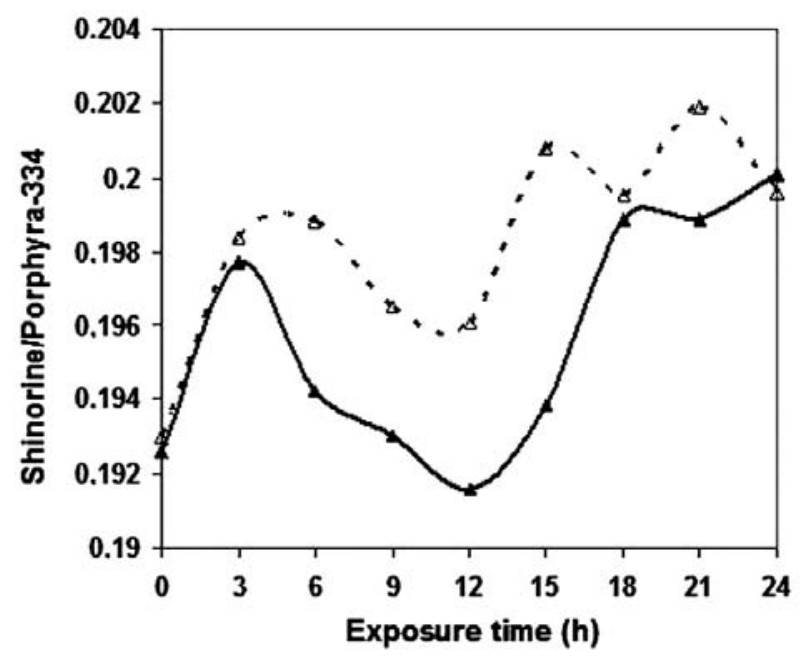

FIG. 7. - Time course of the Shinorine/Porphyra-334 ratio during exposures: Sfixed surface (filled triangles) and vertical mixing (open triangles).

\section{DISCUSSION}

Diatoms generally contain low concentrations of MAAs, with some species even reported to produce no MAAs at all (Jeffrey et al. 1999, Riegger and Robinson 1997, Laurion et al. 2003). However, in agreement with previous reports from Antarctic diatoms (Riegger and Robinson 1997, Hernando et al. 2002), Thalassiosira sp. had high amounts of 2 widely distributed MAAs, Porphyra-334 and Shinorine. Porphyra-334 was the dominant UV-absorbing compound (relative proportion: $82-85 \%$ ) detected in algae in both treatments, whereas Shinorine was present in a lower proportion (relative proportion: 15-18\%). Both compounds have their maximum absorption at $334 \mathrm{~nm}$, in the low UVA range (Neale et al. 1998b). Conde et al. (2004) showed that $\sim 97 \%$ of the absorbed UVB photon energy can be dissipated as heat. The absorption maxima of MAAs is in the 310 to $360 \mathrm{~nm}$ range, and it has been hypothesized that they can act as sunscreens and thus reduce harmful effects of UVR (Carreto et al. 1989). Also, many important molecules, such as cytochromes and catalase, have their absorbance maximum in the UVAR range (White and Jahnke 2002) and might be protected by the MAA screening. Accordingly, Leu et al. (2006) showed an increase in the ratio of the photoprotective pigments diadinoxanthin and diatoxanthin/Chl $a$ content in the Arctic diatom Thalassiosira antarctica var. borealis exposed to UV radiation.

Our experimental data clearly indicate that the MAA synthesis rate is related to the daily light-dark cycle in Antarctic Thalassiosira sp. (Fig. 5a, b). The synthesis of both Porphyra-334 and Shinorine, increased at the beginning of the light period, attained maximum concentrations at the end of the light period, and then decreased towards the beginning of the dark period (Fig. 6). This dependence on total irradiance supports the view that photosynthesis is a necessary prerequisite for the formation of MAA precursors (Bandaranayake 1998). As previously shown in dinoflagellates (Carreto et al. 1990b), the synthesis of these compounds at high irradiances can be abrogated by simultaneous exposure to 3-(3-4-dichlorophenyl)-1, 1-dimethylurea, an inhibitor of photosynthesis. Since the photochemical stability of Porphyra-334 and Shinorine is very high (Conde et al. 2000), the decrease observed during the dark period appears to be the result of a metabolic process induced during darkness. For instance, in the dinoflagellate A. excavatum (=A. tamarense) the synthesis of MAAs is a rapid and partially reversible photosynthesis-dependent process that is arrested by low light conditions and by chemical inhibition of photosynthesis (Carreto et al. 1990a). However, in the red algae Chondrus crispus the synthesis of Shinorine was induced by UVAR plus PAR after a lag phase of one day, after which Shinorine continuously increased its concentration from the beginning of the light exposure and continued during darkness (Kräbs et al. 2004). Recently, a two-stage process for the induc- 
tion of MAAs in the toxic dinoflagellate Alexandrium tamarense was reported (Callone et al. 2006). The first stage involves the net synthesis of mycosporineglycine and the MAAs bi-substituted by amino acids, Porphyra-334 and Shinorine, within the first $2 \mathrm{~h}$ of exposure to higher PAR irradiances. In the second stage these compounds were transformed into other MAAs. In our experiments, the MAA composition of the diatom Thalassiosira sp. did not change during the entire simulated daily exposure cycle and was independent of the light quality conditions, suggesting the lack of expression of some unknown enzymatic systems that used primary MAAs as precursors (Fig. 7), (Carreto et al. 2001, Callone et al. 2006).

Only during the light period, the ratio between the two MAAs was slightly higher in the Mix than the Sfix treatment, owing to a higher rate of Porphyra-334 synthesis in the Sfix $\left(u=0.42\right.$ day $\left.^{-1}\right)$ than in the Mix treatment $\left(\mu=0.40\right.$ day $\left.^{-1}\right)$. However, no significant differences between treatments were observed $(F=3.05$ $P>0.05$ ). Lower solar irradiance had a reducing effect on the synthesis of Porphyra-334. In the Sfix treatment cells were exposed to high daily integrated PAR and UVAR irradiance, whereas the maximum UVBR irradiance and the daily UVBR dose were relatively low (around 20\%) compared to natural spring conditions (Hernando 2011, Hughes 2003) (Table 1) in the Potter Cove area. Similar results were previously reported for a strain of Thalassiosira sp. isolated from the same area (Hernando et al. 2002), which showed that the synthesis rates of both Porphyra-334 and Shinorine during short-term incubations under natural solar radiation depend on PAR intensities, and that any specific role in stimulating or inhibiting MAA synthesis is due to the UVBR. Moreover, in our experimental set-up the $\mathrm{Chl}$ $a$ concentration decreased during the first 6 hours in static surface exposure (Sfix, Fig. 2) when the exposure to UVBR was highest (Fig. 1). Loss of pigmentation or pigment bleaching is a common effect of short-term high UVR exposure (Vernet 2000, Carreto et al. 2002). However, in spite of the Chl $a$ bleaching, the specific rate of synthesis for Porphyra-334 was slightly high. Thus, it appears that Thalassiosira sp. uses the photosynthetic energy gain for the synthesis of photoprotective compounds and presumably re-enforces repair mechanisms at the expense of cellular growth (Fig. 3), as has been shown for the same genus by Hernando $e t$ al. (2002). During this study, Hernando et al. (2002) performed an exposure experiment to total radiation during 6 days using a monospecific culture of Thalassiosira sp. It was shown that the species had an initial period of growth inhibition. The rate of synthesis of MAAs $(\mu)$ was very high in the short-term (hours) and during the 2 first days of the experiment. After 2 days of exposure, however, the MAA content per cell was several times higher than that initially found, and the cells exposed to the PAR+UVR treatment displayed the maximum concentration. These results support the idea that during acclimation the cellular division of
Thalassiosira $s p$. was strongly inhibited by UVR. As the synthesis of MAAs was not affected by UVR, the cells exposed to full solar radiation accumulated more MAAs than those only exposed to PAR.

The stable ratio of MAAs during the light period in the Sfix treatment is indicative of a considerable photostability of both Thalassiosira MAA compounds (Conde et al. 2000), although in both treatments the Shinorine/Porphyra334 ratio declined in the period of highest light (Fig. 7), owing to faster photo-degradation of Shinorine, which was especially evident in the Sfix treatment with higher UVBR irradiation doses. Conde et al. (2004) showed that the photo-degradation of Shinorine in aqueous solution is slightly higher than that of Porphyra-334 under in vitro conditions.

Fixed surface incubations (i.e. not vertically mixed) represent the worst-case scenario for phytoplankton. Samples from the natural environment are exposed to such a radiation regime only when remaining near the sea surface. This is a possible scenario in the area from which the samples were obtained. In Potter Cove, under low wind speed conditions (wind speed $<4 \mathrm{~m} \mathrm{~s}^{-1}$ ) and strong inputs of freshwater from glaciers the water column became more stratified, increasing phytoplankton residence time within the first few metres $(5-10 \mathrm{~m})$ (Schloss and Ferreyra 2002). For Antartica there is evidence of increases in ocean temperature, decreases in ocean $\mathrm{pH}$ and strengthening of the westerly winds at the decadal scale (Meehl et al. 2007). Shallow-mixed layers in the upper part of the water column result in prolonged exposure of cells due to high light and increased UVR penetration, leading to cellular damage as well as inhibiting photosynthesis and growth (Hernando and Ferreyra 2005). Increased vertical stratification and the decrease in the vertical mixed layer depth in Antarctic coastal regions are expected to select species less susceptible to photodamage, with higher rates of repair, and/or other strategies to deal with high light stress (Finkel et al. 2010).

Altogether our data indicate that Thalassiosira sp. from Potter Cove can survive high UVBR exposure in stratified water surfaces. Further, our results document overlapping effects of both daily light cycles and vertical mixing affecting the synthesis of both MAAs. The general decreasing trend in Chl $a$ and in the Shinorine/ Porphyra ratio during the period of maximum light exposure in the natural environment was aligned with the same period in the exposure of cells in the Sfix and Mix treatments. This response is consistent with the observations by Hernando et al. (2002), who reported a lower Shinorine/Porphyra-334 ratio during exposure to the full natural daylight including UVBR and UVAR than in exposure conditions excluding UVBR, and to a lesser extent UVAR. The fact that the ratio remained higher in the Mix than in the Sfix treatment suggests that vertical mixing in Potter Cove may play a photoprotective role. This, together with the high energy dissipation of UVBR by these substances, reflects a highly flexible adaptive response of Thalassiosira sp. 
upon exposure to high irradiance in a stratified water column and the complementary role of vertical mixing in photo-protection.

\section{ACKNOWLEDGEMENTS}

We would especially like to thank Oscar Gonzalez and Leonardo Cantoni, who have supported the operations of this project. We also thank D. Abele and Ann Vanreusel for their comments and suggestions, which helped to improve this manuscript. Our thanks also to the personnel from the Alfred-Wegener-Institut, who shared equipment and results with us in the framework of the Argentinean-German Cooperation at JubanyDallmann in Potter Cove, Antarctica, and especially to Dr. Helmut Tüg and Dirk Wlochowitz for providing instruments and staff for the SONSI project. Funding was supported by the Consejo Nacional de Investigaciones Científicas y Técnicas (Argentina) with a fellowship to Marcelo Hernando and by the Instituto Antártico Argentino.

\section{REFERENCES}

Bandaranayake W. 1998. Mycosporines: are they nature's sunscreens? Nat. Prod. Rep. 15: 159-172.

Banaszak A. 2003. Photoprotective physiological and biochemical responses of aquatic organisms. In: Helbling E.W., Zagarese H.E. (eds.), UV effects in aquatic organisms and ecosystems. The Royal Society of Chemistry, Cambridge, pp. 329-356.

Bracher A., Wiencke C. 2000. Simulation of the effects of naturally enhanced UV radiation on photosynthesis of Antarctic phytoplankton. Mar. Ecol. Progr. Ser. 196: 127-141.

Callone A., Carignan M., Montoya N., Carreto J. 2006. Biotransformation of mycosporine like amino acids (MAAs) in the toxic dinoflagellate Alexandrium tamarense. J. Photochem. Photobiol. B: Biol. 84: 204-212.

Carreto J., De Marco S., Lutz V. 1989. UV-absorbing pigments in the dinoflagellates Alexandrium excavatum and Prorocentrum micans. Effects of light intensity. In: Okaichi, T., Anderson, D., Nemoto, T. (eds.), Red Tides: Biology, Environmental Science and Toxicology. Elsevier Science Publishing Co. Inc. pp. 333-336.

Carreto J., Lutz V., De Marco S., Carignan M. 1990a. Fluence and wavelength dependence of mycosporine-like amino acid synthesis in the dinoflagellate Alexandrium excavatum. In: Graneli E., Edler L., Sundström B., Anderson D.M. (eds.), Toxic marine phytoplankton, Elsevier, New York, pp. 275-279.

Carreto J., Carignan M., Daleo G., De Marco S. 1990b. Occurrence of mycosporine-like aminoacids in the red-tide dinoflagellate Alexandrium excavatum: UV-photoprotective compounds? J. Plankton Res. 12: 909-921.

Carreto J., Carignan M., Montoya N. 2001. Comparative studies on mycosporine-like amino acids, paralytic shellfish toxins and pigment profiles of the toxic dinoflagellates Alexandrium tamarense, Alexandrium catenella and Alexandrium minutum. Mar. Ecol. Progr. Ser. 223: 49-60.

Carreto J., Carignan M., Montoya N. 2002. Short term effects of ultraviolet radiation on the toxic dinoflagellate Alexandrium catenella. Pigment bleaching and MAAs synthesis inhibition. In Brest (ed.) Aquaculture, Environment and Marine Phytoplakton, Ifremer, Actes colloq. 21, pp. 173-189.

Conde F., Churio M., Previtali C. 2000. The photoprotector mechanism of mycosporine-like amino acids. Excited-state properties and photostability of Porphyra-334 in aqueous solution. J. Photochem. Photobiol. B. 56: 139-144.

Conde F., Churio M., Previtali C. 2004. The deactivation pathways of the excited-states of the mycosporine-like amino acids Shinorine and Porphyra-334 in aqueous solution. Photochem. Photobiol. Sci. 3: 960-967.
Cullen J., Lesser M. 1991. Inhibition of photosynthesis by ultraviolet radiation as a function of dose and dosage rate: Results for a marine diatom. Mar. Biol. 111: 183-190.

Davidson A., Bramich D., Marchant H., Mc Minn A. 1994. Effects of UVB irradiation on growth and survival of Antarctic marine diatoms. Mar. Biol. 119: 507-515.

Finkel Z., Beardal 1., Flynn K., Quigg A., Alwyn Rees V., Raven J. 2010. Phytoplankton in a changing world: cell size and elemental stoichiometry. J. Plankton Res. 32(1): 119-137.

Frame E. 2004. Mycosporine-like amino acids (MAAs) in bloom forming phytoplankton: the influence of nitrogen, ultraviolet radiation and species composition. $\mathrm{PhD}$ thesis. University of California, San Diego.

Guillard R., Ryther J. 1962. Studies of marine planktonic diatoms. I. Cyclotella nana Hustedt and Detonula convervacea Cleve. Can. J. Microbiol. 8: 229-239

Helbling E., Chalker B., Dunlap W., Holm-Hansen O., Villafañe V. 1996. Photoacclimation of Antarctic marine diatoms to solar ultraviolet radiation. J. Exp. Mar. Biol. Ecol. 204: 85-101.

Hernando M. 2011. Fitoplancton de altas latitudes en condiciones de ozono disminuido. Editorial Académica Española, Alemania, $300 \mathrm{pp}$.

Hernando M., Ferreyra G. 2005. The effects of UV radiation on photosynthesis in an Antarctic diatom (Thalassiosira sp.): does vertical mixing matter? J. Exp. Mar. Biol. Ecol. 325: 35-45

Hernando M., Carreto J., Carginan M., Ferryra G., Grob C. 2002. Effects of solar radiation on growth and mycosporine-like amino acids content in an Antarctic diatom. Pol. Biol. 25: 12-20.

Hughes K. 2003. Influence of seasonal environmental variables on the distribution of presumptive fecal coliforms around an Antarctic Research Station. Appl. and Environ. Microbiol. 69(8): 4884-4891.

Holm-Hansen O., Lorenzen C., Holmes R., Strickland J. 1965. Fluorometric determination of chlorophyll. J. Cons. Int. Explor. Mer 30: 3-15.

Holm-Hansen O., Riemann B. 1978. Chlorophyll $a$ determination: improvements in methodology. OIKOS 30: 438-447.

Ivanov A., Miskiewicz E., Clarke A., Greenberg B., Huner N. 2000. Protection of photosystem II against UV-A and UV-B radiation in the cyanobacterium Plectonema boryanum: The role of growth temperature and growth irradiance. Photochem. Photobiol. 72: 772-779.

Jeffrey S., MacTavish H., Dunlap W., Vesk M., Groenewoud K. 1999. Occurrence of UVA and UVB-absorbing compounds in 152 species (206 strains) of marine microalgae. Mar. Ecol. Prog. Ser. 189: 35-51.

Karsten U., Bischof K., Hanelt D., Tug H., Wiencke C. 1999. The effect of UV radiation on photosynthesis and UV-absorbing substances in the endemic Arctic macroalga Develaraea ramentacea (Rhodophyta). Physiol. Plant. 105: 58-66.

Kirk J. 1994. Light and photosynthesis in aquatic ecosystems, Cambridge University Press, New York. Great Britain 509 pp.

Klisch M., Häder D. 2002. Wavelength dependence of mycosporinelike amino acid synthesis in Gyrodinium dorsum. J. Photochem. Photobiol. B. 66(1): 60-66.

Kräbs G., Bischof K., Hanelt D., Karsten U., Wiencke C. 2002. Wavelength-dependent induction of UV-absorbing mycosporine-like amino acids in the red alga Chondrus cryspus under natural solar radiation. J. Exp. Mar. Biol. Ecol. 268: $69-82$.

Kräbs G., Watanabe M., Wiencke C. 2004. A monochromatic action spectrum for the photoinduction of the UV-absorbing mycosporine-like amino acid Shinorine in the red alga Chondrus crispus. Photochem Photobiol. 79(6): 515-519.

Laurion I., Blouin F., Roy S. 2003. The quantitative filter technique for measuring phytoplankton absorption: Interference by MAAs in the UV waveband. Limnol. Oceanogr. Methods 1: 1-9.

Leu E., Wängberg S.A., Wulff A., Falk-Petersen S., Ørbæk J.B., Hessen D.O. 2006. Effects of changes in ambient PAR and UV radiation on the nutritional quality of an Arctic diatom (Thalassiosira antarctica var. borealis). J. Exp. Mar. Biol. Ecol. 337: 65-81.

Lubin D., Frederick J., Booth C., Lucas T., Neuschuler D. 1989. Measurement of Enhanced Springtime Ultraviolet Radiation at Palmer Station Antarctica. Geophy. Res. Lett. 16: 783-785

MacDonald T., Dubois L., Smith L., Campbell D. 2003. Sensitivity of cyanobacterial antenna, reaction centre and $\mathrm{CO}_{2}$ assimila- 
tion transcripts and proteins to moderate UVB: Light acclimation potentials resistance to UVB. Photochem. Photobiol. 77: 405-412.

Meehl G., Stocker T., Collins W., Friedlingstein P., Gaye A., Gregory J., Kitoh A., Knutti R., Murphy J., Noda A., Raper S., Watterson I., Weaver A., Zhao Z. 2007. Global climate projections. In: Solomon S., Qin D., Manning M., Chen Z., Marquis M., Averyt K.B., Tignor M., Miller H. (eds.) Climate Change 2007: The Physical Science Basis. Contribution of Working Group I to the Fourth Assessment Report of the Intergovernmental Panel on Climate Change. Cambridge University Press: Cambridge, United Kingdom and New York, NY, USA. http://www.ipcc.ch/ pdf/assessment-report/ar4/wg1/ar4-wg1-spm.pdf (2 April 2008).

Neale P., Banaszak A., Jarriel C. 1998a. Ultraviolet sunscreens in Gymnodinium sanguineum (Dinophyceae) Mycosporine-like amino acids protect against inhibition of photosynthesis. $J$. Phycol. 34: 928-938.

Neale P., Davis R., Cullen J. 1998b. Interactive effects of ozone depletion and vertical mixing on photosynthesis of Antarctic phytoplankton. Nature 392: 585-589.

Portwich A., Garcia-Pichel F. 2000. A novel prokaryotic UVB photoreceptor in the cyanobacterium Chlorogloeopsis PCC 6912. Photochem. Photobiol. 71: 493-498.

Riegger L., Robinson D. 1997. Photoinduction of UV absorbing compounds in Antarctic diatoms and Phaeocystis antarctica. Mar. Ecol. Prog. Ser. 160: 13-25.

Serreze M., Holland M., Stroeve J. 2007. Perspectives on the Arctic's Shrinking Sea-Ice Cover. Science 315: 1533-1536.

Shick J., Lesser M., Jokiel P. 1996. Effects of ultraviolet radiation on corals and other coral reef organisms. Global Change Biol. 2: $527-545$.

Schloss I., Ferreyra G. 2002. Primary production, light and vertical mixing in Potter Cove, a shallow bay in the maritime Antarctic. Polar Biol. 25: 41-48.

Schloss I., Ferreyra G., González O., Atencio A., Fuentes V.,
Tosonotto G., Mercuri D., Sahade R., Tatián M., Abele D. 2008. Long-term hydrographic conditions and climate trends in Potter Cove. Rep. Pol. Mar. Res. 571: 382-389.

Sinha R.P., Richter P., Faddoul J., Braun M., Häder, D.-P. 2002. Effects of UV and visible light on cyanobacteria at the cellular level. Photochem. Photobiol. Sci. 1: 553-559.

Taira H., Fukshima M., Hohsaka T., Sisido M. 2005. Four-base codon-mediated incorporation of no natural amino acids into proteins in a eukaryotic cell-free translation system. J. Biosci. Bioeng. 99(5): 473-476.

Takano S., Uemura D., Hirata Y. 1979. Isolation and structure of a 334 nm UV absorbing substance, Porphyra-334 from red alga Porphyra tenera Kjellman. Chemistry Lett. 419-420.

Tsujino I., Yabe K., Sekikawa I. 1980. Isolation and structure of a new aminoacid, Shinorine, from the red alga Chondrus yendoi Yamada et Mikami. Bot. Mar. 23: 65-68.

Vernet M. 2000. Effects of UV radiation on the physiology and ecology of marine phytoplankton. In: de Mora S., Demers S., Vernet M. (eds.) The effects of $U V$ radiation in the marine environment. Cambridge University Press, Cambridge, pp. 237-278.

Villafañe V., Helbling E., Holm-Hansen O., Chalker B. 1995. Acclimatization of Antarctic natural phytoplankton assemblages when exposed to solar ultraviolet radiation. J. Plankton Res. 17: 2295-2306.

Villafañe V., Reid F. 1995. Métodos de microscopía para la cuantificación del fitoplancton. In: Alveal K., Olivera E. de (eds.), Manual de Métodos Ficológicos. Universidad de Concepción, Concepción, Chile, pp. 169-185.

White A., Jahnke L. 2002. Contrasting Effects of UV-A and UV-B on Photosynthesis and Photoprotection of $\beta$-carotene in two Dunaliella spp. Plant Cell Physiol. 43(8): 877-884.

Scient. ed.: A. Kuwata.

Received May 11, 2010. Accepted July 6, 2011

Published online December 16, 2011. 